\author{
Łukasz Quirini-Popławski \\ https://orcid.org/0000-0002-3583-4916 \\ Uniwersytet Pedagogiczny im. KEN w Krakowie \\ Wydział Geograficzno-Biologiczny \\ Katedra Przedsiębiorczości i Gospodarki Przestrzennej \\ lukasz.quirini-poplawski@up.krakow.pl \\ Nazar Kudła \\ https://orcid.org/0000-0001-9559-4427 \\ Lwowski Uniwersytet Handlu i Ekonomii, Ukraina \\ Wydział Towaroznawstwa Zarządzania i Usług \\ Katedra Zarządzania \\ kudlan@ukr.net \\ Michajło Rytynski \\ https://orcid.org/0000-0003-3142-8723 \\ Lwowski Instytut Ekonomii i Turystyki, Ukraina \\ Wydział Turystyki, Hotelarstwa i Biznesu Restauracyjnego \\ Katedra Turystyki i Hotelarstwa \\ rytynskij@ua.fm
}

\title{
TURYSTYKA W SOWIECKICH KARPATACH. INFRASTRUKTURA NOCLEGOWA DLA TURYSTYKI KWALIFIKOWANEJ W LATACH 70. I 80. XX WIEKU NA OBSZARZE KARPAT WSCHODNICH (OBWODY LWOWSKI I IWANOFRANKOWSKI) ${ }^{1}$
}

\begin{abstract}
Abstrakt: Artykuł jest poświęcony problemowi badawczemu deskrypcji elementów bazy noclegowej dla turystyki kwalifikowanej na terytorium północnego skłonu Karpat Wschodnich w granicach dawnej Ukraińskiej Socjalistycznej Republiki Radzieckiej, w tym jej typów, rozmieszczenia i wielkości. Charakterystyce poddano okres lat 70. i 80. XX w., który uważany jest za złote czasy rozwoju turystyki w Związku Radzieckim. W wyniku analizy dokonano identyfikacji 51 obiektów, w których, w połowie lat 80., było blisko 7,3 tys. miejsc noclegowych. Był to szczytowy okres zagospodarowania tego obszaru.
\end{abstract}

Słowa kluczowe: baza noclegowa, schroniska, turystyka kwalifikowana, Karpaty Wschodnie, Ukraińska Socjalistyczna Republika Radziecka.

\section{WSTĘP}

Przedmiotem zainteresowania autorów artykułu są elementy bazy noclegowej przeznaczone w głównej mierze dla uczestników pieszej i narciarskiej turystyki kwalifikowanej. Badaniami objęto obiekty należące do podmiotów państwowych i organizacji turystycznych, funkcjonujące w latach 70. i 80. XX w. Okres ten uznawany jest przez ukraińskich badaczy za złote czasy (Зоряний uac) w rozwoju turystyki, która wówczas osiągnęła wymiar masowy (Fedorchenko, Dorova, 2002; Savchuk, Kotenko, 2012; Ziuzin, Rozhko, 2019). W niniejszym opracowaniu skoncentrowano się na obszarze północ- nego skłonu Karpat Wschodnich (wytyczonych według podziału Kondrackiego, 1978) w granicach ówczesnej Ukraińskiej Socjalistycznej Republiki Radzieckiej (dalej Ukraińska SRR), obejmujących w całości lub w części grupy górskie: Beskidów Brzeżnych, Beskidów Pokucko-Bukowińskich, Bieszczad Wschodnich, Czarnohory, Gorganów, Gór Czywczyńskich, Gór Sanocko-Turczańskich i Połonin Hryniawskich. Administracyjnie teren zawierał się w granicach ówczesnych obwodów lwowskiego i iwanofrankowskiego. Artykuł opiera się na badaniach obejmujących kwerendę biblioteczną i archiwalną, a także 
inwentaryzację urbanistyczną i dokumentację fotograficzną z lat 2007-2010, uaktualnioną w $2018 \mathrm{r}$.

Próba kwantyfikacji infrastruktury noclegowej dla turystyki kwalifikowanej i jej rozwoju na obszarze Beskidów Wschodnich w okresie Ukraińskiej SRR nie była jak dotąd przedmiotem kompleksowych studiów naukowych ani ukraińskich (czy radzieckich), ani polskich badaczy. Celem autorów niniejszego artykułu jest wypełnienie, przynajmniej częściowo, tej luki poznawczej. $\mathrm{W}$ latach 70. i 80. XX w. powstały jednakże opracowania kartograficzne i przewodnikowe, stanowiące do dziś istotne źródło informacji na ten temat (Burnashov, Hafniak, Hoshovskyi, Drukman, 1973; Chazov, 1983; Sossa, 1987). W późniejszym okresie opublikowano liczne prace o charakterze przyczynkowym, napisane zarówno przez polskich (Dyląg, 2008; Gudowski, 1997; Olszański, Rymarowicz, 1993), jak i ukraińskich autorów (Fedorchenko, Dorova, 2002; Hamkało, Kudła, 2011; Karashec'kyj, Rochnjak, 2010; Kiptenko, Lyubitseva, Malska, Rutynskyi, Zan'ko, Zinko, 2017). Dla porównania rozwój turystycznej bazy noclegowej na obszarze Karpat polskich i Sudetów jest dość dobrze rozpoznany w literaturze naukowej, jak i popularnonaukowej (Biesik, 2010, 2013; Bogdziewicz, 2012; Konieczniak, 2015; Krygowski, 1973, 1988; Mazurski, 2012; Moskała, 1976; 1980, Potocki, 2005, 2009; Staffa, 1994).

Pod koniec lat 30. XX w. na omawianym terenie funkcjonowało 141 schronisk, schronów i stacji noclegowych, w których w 1939 r. było blisko 4,2 tys. miejsc noclegowych. Zagospodarowanie tego obszaru na potrzeby turystyki kwalifikowanej możemy wówczas uznać za odpowiednie (Quirini-Popławski, 2018). Niemal wszystkie górskie schroniska turystyczne zostały zniszczone podczas II wojny światowej. Podobnie w dolinach, gros obiektów uległo destrukcji, pozostałe przebudowano bądź nadawano im inne funkcje, głównie mieszkaniowe.

\section{ZARYS ORGANIZACJI TURYSTYKI ${ }^{2}$}

W okresie międzywojennym podstawą działalności miejscowości turystycznych była Ustawa o uzdrowiskach z marca 1922 r. (znowelizowana w 1928 r.). Sprawy gospodarki turystycznej podlegały ministerstwom Komunikacji, Robót Publicznych, Spraw Wewnętrznych i Zdrowia Publicznego. Wówczas organizacja turystyki była zadaniem nie tylko władz państwowych i samorządowych (na wielu szczeblach), ale także różnych instytucji i federacji. Struktura własnościowa infrastruktury dla turystów była bardzo zróżnicowana (od władz państwowych, przez stowarzyszenia, przedsiębiorców, po prywatne osoby).

W wyniku II wojny światowej nastąpiła zmiana przynależności państwowej obszaru Beskidów Wschodnich, co doprowadziło do przekształcenia modelu organiza- cji turystyki. Zgodnie z ówczesną polityką sektor ten stał się domeną państwa, miał odgrywać bowiem istotną rolę $\mathrm{w}$ polityce społecznej i edukacyjnej Związku Radzieckiego. Według założeń przemiana podejścia do turystyki miała polegać na przejściu z jej elitarnego i bardziej indywidualnego charakteru na zorganizowany i dostępny szerokim warstwom społecznym. To umasowienie turystyki służyło także kreowaniu określonych postaw społecznych. W nowym systemie kładziono nacisk zarówno na elementy psychicznej i fizycznej odnowy, jak i formację ideologiczną. Infrastruktura turystyczna została upaństwowiona i podlegała Centralnej Radzie Związków Zawodowych. Wyjątek stanowiły wybrane domy wypoczynkowe będące własnością poszczególnych urzędów, instytucji czy zakładów pracy (Chazov, 1983; Gorsuch, 2003; Jackowski, 1979; Maurer, 2006; Orlov, 2014; Palmer, 2011; Quirini-Popławski, 2015).

Zauważalne zmiany były widoczne od połowy lat 60 . XX w. (np. w 1965 r. utworzono w obwodach lwowskim i iwanofrankowskim rady do spraw turystyki). Kluczowe znaczenie miało jednak Rozporządzenie Rady Ministrów ZSRR (1969 r.) w sprawie „środków dla dalszego rozwoju turystyki i wycieczek w kraju". Dało ono formalne podstawy do organizacji m.in. stref rekreacji, turystyki i sportu dla mieszkańców miast. Dokument ten zawierał plan budowy infrastruktury na lata 1971-1975 (w tym hoteli, baz turystycznych, kempingów i tzw. autopensjonatów) oraz publikacji materiałów promocyjnych, a także wskazanie przez władze republik działek pod inwestycje turystyczne. Koordynacje wykonania tego planu powierzono Ukraińskiej Republikańskiej Centralnej Radzie Turystyki i Wycieczek wraz z jej obwodowymi i rejonowymi oddziałami, które były odpowiedzialne za rozwój turystyki masowej. Kolejny plan zapowiedziano na lata 1986-1990, ale jego zapisy nie zostały wcielone w życie (DALO fond 3105, opis 1, sprawa 61, 1; Doljenko, Putrik, 2010; Fedorchenko, Dorova, 2002; Kotenko, 2015).

$\mathrm{W}$ czasach autonomii galicyjskiej poruszanie się po Beskidach Wschodnich nie podlegało żadnym ograniczeniom. Podczas dwudziestolecia międzywojennego wymagało to już uzyskania przepustek w starostwach lub (po 1925 r.) przynależności do organizacji turystycznych. Mimo zmian granic po 1945 r. omawianą część łańcucha karpackiego rozdzielała nie państwowa, a obwodowa granica. Przez cały okres radziecki swobodną penetrację turystyczną ograniczały zakazy $\mathrm{w}$ poruszaniu się między obwodami oraz strefy bezpieczeństwa wzdłuż naftociągów (Drużba) i gazociągów (Bractwo, Sojuz) (Nedashkovskaia, 1983). Dodatkowo z powodu bliskiego przebiegu granicy z Rumunią południowa część Połonin Hryniawskich i Gór Czywczyńskich (na południe od szczytu Pop Iwan) była zamkniętą strefą pograniczną, niedostępną dla ruchu turystycznego. Wzdłuż samej granicy państwowej wydzielono pas ogrodzony podwójną liną zasieków, tzw. sistemy. W okresie sowieckim turystykę kwalifikowaną zaliczono do dyscyplin 
sportowych. Powyżej den dolin karpackich mogła być rozwijana jedynie turystyka o charakterze zorganizowanym. Grupy prowadzone przez przewodników po określonych szlakach były zobligowane do codziennego meldowania się we wskazanych punktach kontrolnych (Gudowski, 1997).

\section{INFRASTRUKTURA NOCLEGOWA}

\subsection{TYPY OBIEKTÓW NOCLEGOWYCH}

Usługi dla uczestników kwalifikowanych form turystyki świadczono w różnych typach obiektów. Najpopularniejszym elementem infrastruktury były bazy turystyczne (turbazy), które zgodnie z ówcześnie obowiązującą klasyfikacją możemy określić jako obiekty noclegowe z wyżywieniem, służące szeroko rozumianemu wypoczynkowi, dostosowane do obsługi uczestników zorganizowanego ruchu turystycznego, najczęściej autokarowego. W praktyce przyjmowano zarówno osoby ze skierowaniami, w tym rodziców z dziećmi, jak i uczestników turystyki indywidualnej. Istotnym wyróżnikiem baz turystycznych było organizowanie tam imprez o charakterze masowym, takich jak: rajdy, zawody, wycieczki krajoznawcze. Wyróżniano obiekty otwarte i zamknięte, te drugie były dostępne dla członków określonego stowarzyszenia, klubu czy pracowników danego zakładu pracy. Modelowa turbaza obejmowała część noclegową dla kilkuset osób, gastronomiczną, świetlicę, magazyn sprzętu turystycznego i sportowego. Często organizowano filie w słabiej dostępnych obszarach (np. w wyżej położonych miejscowościach lub osiedlach). W zależności od profilu turbazy były wyposażone w liczne dodatkowe elementy infrastruktury, m.in.: parkingi, kasy biletowe, place sportowe, pola namiotowe, szlaki turystyczne, wyciągi narciarskie lub stanice wodne. $\mathrm{Z}$ uwagi na uwarunkowania środowiskowe na obszarach górskich często lokowano bazy sportowe, poświęcone głównie zimowym dyscyplinom (Chazov, 1983).

Niezależnie od baz, jako odrębne elementy zagospodarowania, powstawały tzw. prijuty (nрuют). To rodzaj schronisk przeznaczonych przede wszystkim dla uczestników zorganizowanych wycieczek pieszych, choć nierzadko udostępniano je również turystom indywidualnym. Lokalizowane były poza głównymi ciągami komunikacyjnymi - w Karpatach z reguły w dolinach górskich rzek wzdłuż szlaków turystycznych. Były to obiekty mniejsze, bardziej prymitywne od baz, o przeciętnej pojemności do 100 miejsc.

Trzeci typ infrastruktury noclegowej wykorzystywany na potrzeby turystyki kwalifikowanej stanowity obozy. Możemy je zdefiniować jako formy organizacji wypoczynku, najczęściej letniego, przeznaczone dla dzieci i młodzieży w specjalnie do tego celu przystosowanych obiektach lub namiotach. Były to obozy sportowe, wypoczynkowe, lecznicze lub turystyczne. Do najpopularniejszych należały te o profilu wypoczynkowo-leczniczym, na które wymagana była "karta sanatoryjno-kurortowa”. Organizowały je zrzeszenia komsomolskie, kluby pionierów i skautów. Założenie obozowe składało się z obiektów sezonowych, o konstrukcji nietrwałej, domków kempingowych bądź namiotów, dlatego niejednokrotnie lokowano je przy domach wczasowych, których infrastruktura była wykorzystywana przez obozowiczów. Uczestnicy wypoczywali według ściśle określonego planu dnia, obejmującego aktywność fizyczną (gry sportowe, wędrówki, prace w gospodarstwie), kulturalną (projekcje filmów, prelekcje) i umysłową (zajęcia dokształcające i krajoznawcze, nabywanie sprawności). Specyficznym typem były tzw. obozy pionierskie (pierwszy odbył się w 1925 r.), które odgrywały szczególną rolę w systemie edukacji narodowej i formowaniu postaw społecznych dzieci i młodzieży w Związku Radzieckim. W tym przypadku program obejmował dodatkowo uczestnictwo w zajęciach ideologicznych, takich jak: spotkania z bohaterami wielkiej wojny ojczyźnianej, manifestacje, lektura prasy i czasopism (Chazov, 1983; De Witt, 1961; Katel, 1968; Korzhev, 1963; Peacock, 2014; Resnick, 1985; Rudenko, 1985; Sossa, 1987).

Warto wspomnieć, że uczestnicy kwalifikowanych form turystki korzystali również z ośrodków wypoczynkowych. W gruncie rzeczy były to obiekty środowiskowe, przeznaczone dla pracowników danego zakładu i ich rodzin, będące w gestii związków zawodowych i udostępniane tylko na podstawie skierowań. $W$ Beskidach Wschodnich możemy wyróżnić trzy miejsca koncentracji takich ośrodków - dolina Oporu poniżej Synowódzka Wyżnego, rejon Schodnicy i dolina Prutu między Jaremczem a Worochtą (Quirini-Popławski, 2015).

\subsection{ROZWÓJ INFRASTRUKTURY}

Właściwie nie można mówić o inwestycjach rozpoczętych z myślą o uczestnikach turystyki kwalifikowanej w Beskidach Wschodnich w latach 40. i 50. XX w. Jedną z pierwszych nowych realizacji z okresu powojennego była turystyczna baza pod nazwą "Huculszczyzna”, wzniesiona w latach 1961-1963 (później jeszcze rozbudowana) w dzielnicy Jaremcza-Kamień Dobosza nad Prutem. Składała się z rozległego budynku głównego (mieszczącego część gastronomiczną, świetlicę, bibliotekę, salę projekcyjną, wypożyczalnię sprzętu turystycznego, saunę), trzech 3-kondygnacyjnych obiektów noclegowych (oferujących 2-4-osobowe pokoje) oraz kilku domów letniskowych dla uczestników obozów młodzieżowych. W sąsiedztwie w stylowym budynku działała restauracja „Huculszczyzna”. Była to jedna z pokazowych inwestycji, do której kierowano grupy w ramach wymiany międzynarodowej za pośrednictwem biura "Turist". 
Na terenie tego obiektu znajdowały się także: plac przeznaczony do odbywania apeli, boisko sportowe, pole namiotowe dla 100 osób, urządzony park, parking i zaplecze techniczne. W ofercie bazy zawarte były różnorodne usługi, w tym realizacja połączeń międzynarodowych czy rezerwacja biletów kolejowych i lotniczych. Maksymalna pojemność w sezonie letnim wynosiła 600 miejsc noclegowych (zimą 420). Była to największa baza w ukraińskich Karpatach. Stworzono ją dla grup zorganizowanych i rodzin, choć $\mathrm{w}$ przypadku wolnych miejsc z noclegów mogli korzystać również turyści indywidualni. Filią turbazy w Jaremczu był zespół pawilonów noclegowych (częściowo sezonowych) o nazwie "Czarnohora”, zaaranżowany dla 120 osób w Zawojeli koło Worochty w dolinie Prutu (Burnashov, Hafniak, Hoshovskyi, Drukman, 1973; Chazov, 1983; Czubiński, 2008, 2014; Krasyi, 1976; Sossa, 1987; Zavalyi, Yonkyn, 1967).

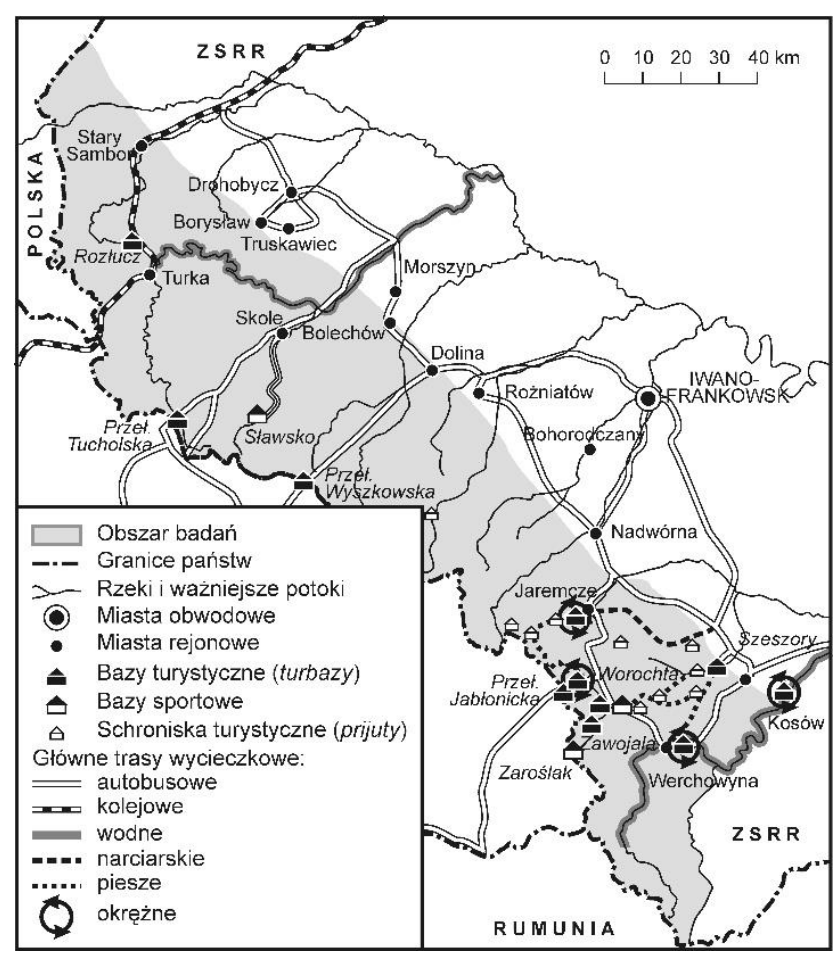

Rysunek 1. Rozmieszczenie bazy noclegowej dla turystyki kwalifikowanej i szlaki wycieczkowe rangi ogólnozwiązkowej wBeskidach Wschodnich w latach 80. XX w.

Źródło: opracowanie autorów na podstawie badań terenowych oraz publikacji: Horbunov (1969), Krasyi (1976), Khvostenko

(1976), Rudenko (1985), Burnashov (1986), Sossa (1987)

Od połowy lat 70. XX w. sytuacja $\mathrm{w}$ zakresie zagospodarowania zmieniła się dość wyraźnie. Powstało wówczas wiele dużych, dobrze skomunikowanych i urządzonych turbaz do obsługi zorganizowanych wycieczek oraz rodzin $\mathrm{z}$ dziećmi czy indywidualnych turystów (w przypadku wolnych miejsc). Najwięcej z tych obiektów zbudowano w miejscowościach będących dogodnymi punktami wyjścia w masywy Czarnohory i Beskidów Pokucko-Bukowińskich. W Kosowie wzniesiono 4-kondygnacyjny budynek („Karpacki Świt”), składający się z części noclegowej i gastronomiczno-rekreacyjnej, który dysponował 300 całorocznymi miejscami noclegowymi i własnym wyciągiem narciarskim. Równie szeroki program usług towarzyszących miała baza turystyczna usytuowana w centrum Jabłonicy (,Gornaja”). W pięciu stylowych drewniano-murowanych budynkach przewidziano 150 miejsc noclegowych oraz część gastronomiczną i techniczną. W rejonie przedwojennego schroniska wzniesiono na Przełęczy Jabłonickiej (Tatarskiej) obiekt w standardzie hotelowym o nazwie „Berkut", w którym znajdowały się: kilkadziesiąt pokoi, duża stylowa restauracja, zadaszone miejsca parkingowe i kilka wyciągów. W ścisłym centrum Worochty, naprzeciw dworca kolejowego, wybudowano 2-kondygnacyjny obiekt o nazwie „Karpaty” dla 44 osób, oferujący jedynie podstawowe usługi. We wsi Szeszory działała popularna baza sezonowa „,Srebrne Wodospady”, mogąca pomieścić maksymalnie 410 osób w domkach letnich (rys. 1). Nieco później (1982 r.) oddano do użytku pokaźną turbazę „Werchowyna” w Werchowynie (dawniej Żabie), składającą się z dwóch kilkupiętrowych obiektów noclegowych (300 miejsc) oraz budynku mieszczącego dużą salę sportową i kinową. Obok zorganizowano place i boiska sportowe (Burnashov, Hafniak, Hoshovskyi, Drukman, 1973; Chazov, 1983; Khvostenko, 1976; Krasyi, 1976; Nedashkovskaia, 1983; Sossa, 1987).

W zachodniej części Beskidów Wschodnich nasycenie infrastrukturą było mniejsze. W pierwszej połowie lat 70. XX w. wybudowano stosunkowo niewielką (około 100 miejsc) bazę „Przełęcz”, malowniczo położoną w rejonie przełęczy Tucholskiej (Wereckiej). Z kolei najbardziej na zachód położonym obiektem dla turystyki kwalifikowanej było „Джерело Карпат” („Źródło Karpat”) znajdujące się w północnej części Rozłucza w Górach Sanocko-Turczańskich. Wzniesiono tam zespół czterech 2- i 3-kondygnacyjnych budynków z urządzonym zapleczem rekreacyjnym dla 140 osób. Mimo konstrukcji murowanej działał jedynie sezonowo, od maja do października (Rutynskyi, 2012; Sossa, 1987).

Kolejną grupę stanowiły bazy sportowe, które miały z zasady charakter obiektów niedostępnych dla turystów indywidualnych. Z myślą o organizacji Zimowych Igrzysk Olimpijskich w ukraińskich Karpatach planowano budowę ośrodka sportów zimowych w Worochcie. W związku z tym w centrum tej miejscowości zlokalizowano duży ośrodek szkoleniowy z zapleczem noclegowym, gastronomicznym i internatem $\mathrm{w}$ obiektach "Skocznia" i „Ukraina”, łącznie dla 750 osób. Ponadto na polanie Zaroślak (1278 m n.p.m.) w Czarnohorze, po wyburzeniu ruin dawnego schroniska, oddano do użytku w 1974 r. znacznych rozmiarów kompleks radzieckiej kadry narodowej, w którym sportowcy mieli się przygotowywać do igrzysk olimpijskich ${ }^{3}$. Był to najwyżej położony obiekt noclegowy w Beskidach Wschodnich. Dwuskrzydłowy budynek mieścił ok. 40 pokoi, jadal- 
nię, zaplecze rekreacyjne, salę gimnastyczną oraz liczne mniejsze pomieszczenia dla gości i obsługi. Baza była przystosowana do całorocznego funkcjonowania. Przyjmowała grupy radzieckich, ukraińskich, gruzińskich i białoruskich sportowców. Jednocześnie w Sławsku w Bieszczadach wybudowano, na miejscu wcześniej wykorzystywanego drewnianego budynku, bazę „,Dynamo" o standardzie hotelowym. Wyposażona była ona w pokoje dla ponad 150 gości, saunę, salę sportową i własną stację narciarską. Kolejną realizacją przeznaczoną głównie dla grup sportowców była baza "Czeremosz" w Werchowynie (100 miejsc), z własnym stadionem piłkarskim, lekkoatletycznym i trzema skoczniami narciarskimi. Funkcjonował tu również ośrodek szkoleniowy (Burnashov, 1986; Nabytovych, Protsailo, 2006; Rudenko, 1985; Shulha, Onufriv, 2013).

Wszystkie schroniska (tzw. prijuty) zostały zgrupowane w Beskidach Pokucko-Bukowińskich (sześć) i wschodniej części Gorganów (trzy) w większości w pierwszej połowie lat 70. XX w. Ich układ przestrzenny umożliwiał swobodną organizację okrężnych wycieczek pieszych i narciarskich. W schroniskach tych umieszczono punkty kontrolne, w celu rejestrowania się wycieczek, i posterunek górskiej służby ratowniczej. Przykładowo całoroczne schronisko „Doboszanka” na zachód od Jaremcza urządzono $\mathrm{w}$ drewnianym domu $\mathrm{z}$ wysokim poddaszem przystosowanym do przyjmowania gości zbiorowych. Wyposażone było w kuchnię, magazyn sprzętu turystycznego i pole biwakowe. Ponadto w latach 70. XX w. w zaadaptowanym obiekcie zorganizowano prjut w Osmołodzie. Łączna pojemność 10 schronisk w Beskidach Wschodnich kształtowała się na poziomie blisko 1000 miejsc noclegowych.

Dla dzieci i młodzieży zorganizowano oddzielne bazy turystyczne. Dużym zgrupowaniem tej infrastruktury odznaczała się dolina Oporu. Jako pierwszą, w 1955 r., założono w Dębinie pod Skolem bazę namiotową „Karpaty", przekształconą z czasem w kompleks kilku budynków noclegowych. Maksymalna pojemność w sezonie wynosiła 180 miejsc, w tym 80 w letnich domkach. Największy tego typu kompleks o nazwie „Hucułka” powstał w 1970 r. w Schodnicy w Beskidach Brzeżnych (rys. 2). Miał on charakter wypoczynkowo-leczniczy i składał się z ośmiu budynków mieszkalnych (ok. 300 łóżek), dwóch jadalni i świetlicy. We wschodniej części Beskidów Wschodnich uruchomiono z czasem kolejne trzy całoroczne bazy, które były usytuowane w centralnych częściach miejscowości Jabłonica („Karpaty”), Jaremcze („Prut”) i Worochta („Howerla"). Razem mogły pomieścić blisko 250 osób. Z kolei (prawdopodobnie w latach 80. XX w.) otwarto w Wyszkowie w Gorganach niewielki obiekt noclegowy "Krokus”, należący do organizacji o nazwie Sputnik. Przeznaczony był dla międzynarodowych grup młodzieży z krajów socjalistycznych (Zinchenko, 2004). Ponadto bazy turystyczne dla dzieci i młodzieży działały w Sławsku („Połonina”) i Skole („,Werchowyna”).

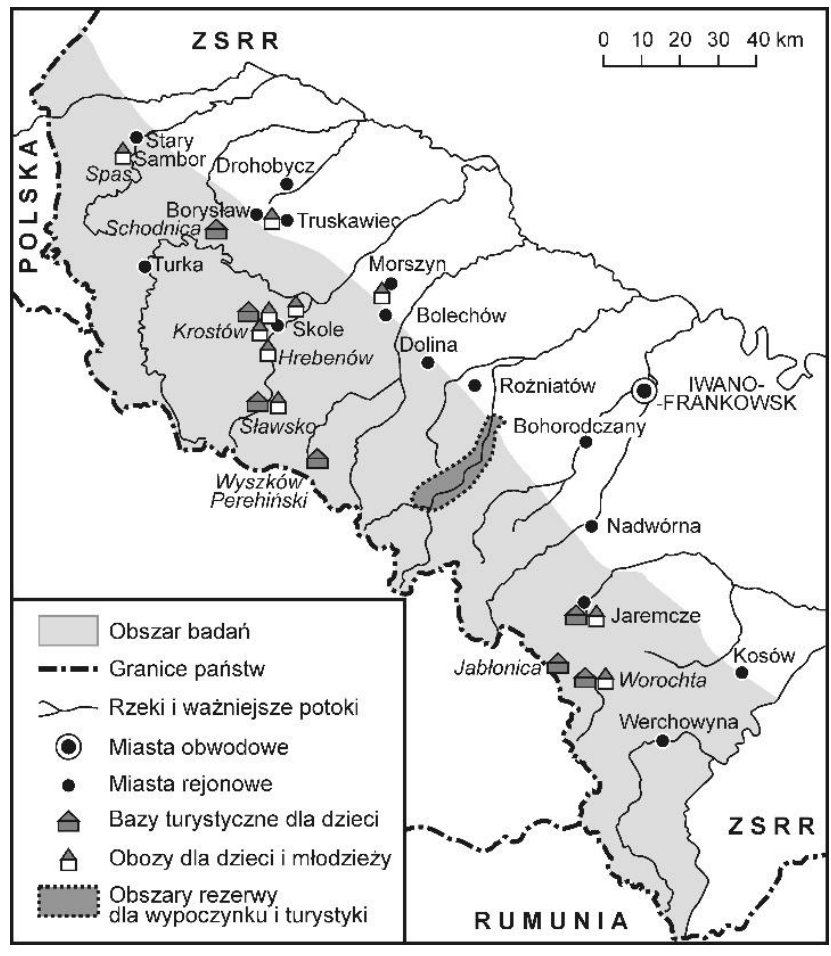

Rysunek 2. Rozmieszczenie bazy noclegowej dla turystyki kwalifikowanej dzieci i młodzieży w Beskidach Wschodnich w latach 80. XX w.

Źródło: opracowanie autorów na podstawie badań terenowych oraz publikacji: Krasyi (1976,) Sossa (1987), Sovetskoe... (1989)

Jak już wcześniej wspomniano, szczególnym typem zagospodarowania dla zorganizowanych grup dzieci i młodzieży były obozy, w tym pionierskie, których najwięcej funkcjonowało w dolinie Oporu i Prutu na terenie Beskidów Wschodnich oraz w dużych uzdrowiskach - Truskawcu i Morszynie (rys. 2). Rejonami szczególnej koncentracji były południowe dzielnice Jaremcza - Kamień Dobosza i Hrebenowa - w dolinie potoku Hrebenowiec, gdzie tworzyły swoiste dzielnice o jednolitym przeznaczeniu. Obozy lokalizowano z reguły na peryferiach miejscowości turystycznych, blisko granicy lasu, często nad ciekami wodnymi. Modelowe założenie składało się z budynku głównego i wielu domków o lekkiej konstrukcji ścian i dachu bądź grupy kilkuosobowych namiotów. Charakterystyczną cechą był ich koncentryczny układ z centralnie położonym placem do odbywania apeli. Średnia powierzchnia kształtowała się na poziomie kilkunastu arów, choć obozy „Trembita” w Sławsku $i$ „Watra” w Hrebenowie zorganizowano na powierzchni ponad 1 ha. Obiekty tworzono zwykle z nietrwałych materiałów budowlanych, bez fundamentów. Z uwagi na wysokie koszty eksploatacji często prowizoryczna zabudowa cechowała się krótkim okresem wytrzymałości technicznej i stosunkowo szybko ulegała dekapitalizacji, zwłaszcza przy braku konserwacji w okresie zimowym. Pod koniec lat 80. XX w. w Beskidach Wschodnich funkcjonowało co najmniej 17 obozów ze stałą infrastrukturą. Należy jednak przypuszczać, że organizowano 
ponadto liczne kolonie letnie w doraźnych lokalizacjach i obiektach tymczasowych (Rudenko, 1985; Sossa, 1987; Stotska, 1997).

\section{CHARAKTERYSTYKA INFRASTRUKTURY NOCLEGOWEJ}

Od końca lat 60. XX w. intensywnie rozwijano w Związku Radzieckim badania w zakresie zagospodarowania przestrzennego na potrzeby turystyki i rekreacji. Rozwój miejscowości turystycznych i lokalizacje poszczególnych elementów zagospodarowania turystycznego w Beskidach Wschodnich następowały w sposób zamierzony na podstawie planów zagospodarowania sporządzanych w różnych skalach przestrzennych. Trzeba jednak zaznaczyć, że ówczesne dokumenty planistyczne przeznaczone na potrzeby turystyki były swoistymi studiami możliwości, programami zakładającymi maksymalizację i przede wszystkim zaspokojenie zapotrzebowania społecznego. Przyjęto zasadę koncentracji infrastruktury w określonych miejscowościach, pozostawiając między nimi tereny zalesione bez prawa zabudowy, które stanowiły naturalny rezerwuar terenów rekreacyjnych (np. w Gorganach w rejonie Perehińska). Duże zapotrzebowanie na nowe obiekty wiązało się ze znacznym wzrostem poziomu zatrudnienia $\mathrm{w}$ przemyśle $\mathrm{w}$ pobliskich dużych ośrodkach miejskich - Lwowie i Iwano-Frankowsku. Spośród pozytywnych przykładów praktyki planistycznej należy wymienić wdrożone w latach 80 . XX w. na obszarze Karpackiego Parku Narodowego opracowanie, na podstawie którego wydzielono strefy funkcjonalne: ochronną, z wiodącą działalnością naukowo-badawczą (8 tys. ha), i rekreacyjną, dla obsługi masowej turystyki i wczasowiczów. Równocześnie wiele miejscowości w dolinie Prutu objęto planami zagospodarowania przestrzennego (Dolyshnyi, 1988; Nefedova, Smyrnova, Chyzhova, Shvydchenko, 1980).

Z jednej strony wiele obiektów turystycznych, o których wspomniano $w$ niniejszym opracowaniu, było wyposażonych $\mathrm{w}$ nowoczesne ówcześnie elementy infrastruktury technicznej i uzupełniającej (tab. 1). Dotyczy to zwłaszcza dużych baz turystycznych, np. w Jaremczu, Werchowynie i Szeszorach. W niektórych budynkach można było korzystać $\mathrm{z}$ takich udogodnień, jak: międzynarodowe połączenia telefoniczne, sauna, sala kinowa i gimnastyczna. Inne były bardzo dobrze przygotowane do przyjęcia grup turystów zmotoryzowanych (Jaremcze, Przełęcz Jabłonicka) i wyposażone w rozbudowaną infrastrukturę do obsługi pojazdów. $Z$ drugiej strony wiele sezonowych założeń obozowych miało tylko podstawowe, prymitywne wyposażenie (brak ciepłej wody, wodociągów i kanalizacji, nietrwała konstrukcja budynków, brak utwardzonej drogi dojazdowej).
Wszystkie bazy turystyczne były przeznaczone do całorocznego użytkowania. Wyjątek stanowiły obiekty w Szeszorach i Rozłuczu. Modelowy kompleks w Beskidach Wschodnich składał się z 2-3 budynków, restauracji lub stołówki, parkingu i pola namiotowego. Zróżnicowana była ich pojemność - najmniejsze na Przełęczy Wyszkowskiej i w Jaremczu („Karpaty”), dla mniej niż 50 osób, największy zaś w Jaremczu („Huculszczyzna”) dla 600 gości. Pod względem liczby baz turystycznych w ówczesnej Ukraińskiej SRR, 8\% stanowiły obiekty położone w Beskidach Wschodnich. Ogólna liczba miejsc noclegowych $\mathrm{w}$ drugiej połowie lat 80 . XX w. kształtowała się na poziomie 2400-2500. Trzeba jednak dodać, że strona zakarpacka była zagospodarowana na podobnym poziomie, funkcjonowało tam 12 turbaz, bardziej rozproszonych, ale o mniejszej łącznej pojemności - ok. 1700 miejsc (Burnashov, Hufniak, Hoshovskyi, Drukman, 1973; Chazov, 1983; Khvostenko, 1976; Krasyi, 1976; Nedashkovskaia, 1983; Sossa, 1987).

W wyniku badań dokonano identyfikacji 51 obiektów, w których w połowie lat $80 . \mathrm{XX}$ w. było blisko 7,3 tys. miejsc noclegowych (tab. 2). Zagospodarowanie opisywanego obszaru w tym okresie osiągnęło szczyt. Pod względem ilościowym największą część stanowiły sezonowe obozy dla dzieci i młodzieży (17 obiektów, 1675 łóżek), ale to w 11 bazach turystycznych zlokalizowano $1 / 3$ wszystkich miejsc noclegowych (2384). Średnia pojemność bazy noclegowej wynosiła 142 łóżka/obiekt, przy czym bazy sportowe charakteryzowały się przeciętną pojemnością niemal 250 łóżek/obiekt, z kolei schroniska - poniżej 100. Generalnie Beskidy Pokucko-Bukowińskie, doliny Prutu i Oporu odznaczały się dobrym zagospodarowaniem. Celowo z planów inwestycyjnych zostały wyłączone Góry Czywczyńskie i Połoniny Hryniawskie (bliskość granicy z Rumunią), ponadto środkowa i zachodnia część Gorganów. Jak podaje Nedashkovskaia (1983), w planach były kolejne inwestycje noclegowe: baza narciarska w Jaremczu (150 miejsc), Worochcie (100 miejsc) i Rozłuczu (500 miejsc), schroniska w Bistricy (daw. Rafajłowej), Tucholce, Skolu i Schodnicy.

Wydaje się, że w czasach Związku Radzieckiego, $\mathrm{z}$ racji swojego peryferyjnego, przygranicznego położenia i historycznej przynależności, Karpaty były terenami, które nie cieszyły się dużym zainteresowaniem inwestycyjnym, pomimo bogactwa ich walorów przyrodniczych i antropogenicznych ${ }^{4}$. W pierwszych kilkunastu powojennych latach ruch turystyczny poza uzdrowiskami praktycznie zamarł, był ograniczony do pobytów o charakterze kuracyjnym. Do połowy lat $50 . X X$ w., $\mathrm{z}$ uwagi na walki sowieckich sił bezpieczeństwa $\mathrm{z}$ oddziałami Ukraińskiej Powstańczej Armii, obszar powyżej den dolin był wyłączony z turystycznej penetracji. Kolejne dekady przyniosły zmianę tej sytuacji, nastąpił wówczas bardziej intensywny rozwój turystyki kwalifikowanej, a w kolejnych latach zjawisko przyjęło formę 
Tabela 1. Wyposażenie w elementy infrastruktury wybranych obiektów noclegowych w Karpatach Wschodnich

\begin{tabular}{|c|c|c|c|c|c|c|c|c|}
\hline \multirow{2}{*}{$\begin{array}{c}\text { Położenie } \\
\text { obiektu }\end{array}$} & \multicolumn{8}{|c|}{ Element infrastruktury } \\
\hline & $\begin{array}{c}\text { centralne } \\
\text { ogrzewanie }\end{array}$ & telefon & $\begin{array}{c}\text { wyciąg } \\
\text { narciarski }\end{array}$ & $\begin{array}{c}\text { wypożyczalnia } \\
\text { sprzętu sportowego }\end{array}$ & $\begin{array}{c}\text { sala } \\
\text { kinowa }\end{array}$ & $\begin{array}{l}\text { rezerwacja biletów } \\
\text { komunikacyjnych }\end{array}$ & parking & kolej \\
\hline Jabłonica & + & + & + & + & + & - & + & - \\
\hline Jaremcze & + & + & - & + & + & + & + & + \\
\hline Kosów & + & + & + & + & + & + & + & - \\
\hline Rozłucz & - & - & - & + & - & - & - & + \\
\hline Szeszory & - & + & - & + & + & + & + & - \\
\hline Werchowyna & + & + & - & + & + & + & + & - \\
\hline Zaroślak & + & b.d. & - & - & + & - & + & - \\
\hline
\end{tabular}

Objaśnienia: (+) - dostęp do danego elementu infrastruktury, (-) - brak dostępu do danego elementu infrastruktury, b.d. - brak danych.

Źródło: opracowanie autorów na podstawie Sossa (1987) oraz badań terenowych.

Tabela 2. Baza noclegowa dla turystyki kwalifikowanej w Karpatach Wschodnich w latach 80. XX w.

\begin{tabular}{|c|c|c|c|c|c|c|c|}
\hline \multirow[b]{2}{*}{ Grupy górskie } & \multicolumn{6}{|c|}{ Liczba obiektów noclegowych według typów } & \multirow{2}{*}{$\begin{array}{l}\text { Liczba miejsc } \\
\text { noclegowych }\end{array}$} \\
\hline & turbazy & $\begin{array}{c}\text { bazy } \\
\text { sportowe }\end{array}$ & $\begin{array}{c}\text { schroniska } \\
\text { (prijuty) }\end{array}$ & $\begin{array}{l}\text { bazy dla dzieci } \\
\text { i młodzieży }\end{array}$ & $\begin{array}{l}\text { obozy dla dzieci } \\
\text { i młodzieży }\end{array}$ & $\begin{array}{l}\text { obiekty } \\
\text { ogółem }\end{array}$ & \\
\hline $\begin{array}{l}\text { Góry Sanocko- } \\
\text {-Turczańskie }\end{array}$ & 1 & 0 & 0 & 0 & 0 & 1 & 140 \\
\hline Bieszczady Wschodnie & 2 & 1 & 0 & 3 & 4 & 10 & 1070 \\
\hline Beskidy Brzeżne & 0 & 0 & 0 & 1 & 7 & 8 & 1000 \\
\hline Gorgany & 3 & 0 & 4 & 3 & 5 & 15 & 2080 \\
\hline Czarnohora & 2 & 3 & 0 & 1 & 1 & 7 & 1229 \\
\hline $\begin{array}{l}\text { Beskidy Pokucko- } \\
\text {-Bukowińskie }\end{array}$ & 3 & 1 & 6 & 0 & 0 & 10 & 1720 \\
\hline Karpaty Wschodnie & 11 & 5 & 10 & 8 & 17 & 51 & 7239 \\
\hline
\end{tabular}

W przypadku braku danych o liczbie miejsc noclegowych założono liczbę 100.

Źródło: opracowanie autorów na podstawie Krasyi (1976), Nedashkovskaia (1983), Rudenko (1985), Sossa (1987) oraz badań terenowych.

powszechną i masową. Proces rozwoju turystyki rozpoczął się więc o 10-20 lat później niż w pozostałych karpackich regionach.

W ścisłym związku z rozmieszczeniem przestrzennym bazy noclegowej wytyczono w Beskidach Wschodnich główne (rangi ogólnozwiązkowej) trasy wycieczek, w szczególności dla turystyki pieszej i narciarskiej. Przeciętny czas trwania wycieczki wynosił ok. $20 \mathrm{dni}$ i obejmował zarówno piesze wędrówki i spływy rzekami (zimą wędrówki narciarskie), jak i pobyty stacjonarne w bazach turystycznych. De facto znakowano szlaki na niewielkich odcinkach (m.in. w Czarnohorze i Beskidach Pokucko-Bukowińskich), choć czasem brakowało ich nawet $\mathrm{w}$ rejonie istniejących obiektów w dolinie Prutu. W planach była budowa (podobne jak w Polsce) magistrali turystycznej biegnącej wzdłuż całego łańcucha Karpat (Nedashkovskaia, 1983). Najbardziej powszechne były grupowe wycieczki autokarowe, dlatego znacząco rosła liczba szlaków dla turystów zmotoryzowanych. Wśród najważniejszych należy wymienić letni „Szlak Karpacki" prowadzący ze Lwowa przez Jaremcze do Rachowa i Mukaczewa, „Podkarpackie Wodospady”
- szlak górski między Szeszorami, Jaremczem a Jabłonicą, szlak „Do Kraju Karpackich Mistrzów” w rejonie Jaremcza i Kosowa, a także liczne zimowe szlaki: „Karpackie Gwiazdy" w Beskidach Pokucko-Bukowińskich, "Zimowa Huculszczyzna” i „Po Huculszczyźnie” - oba narciarskie, $w$ rejonie Jaremcza (rys. 1).

O dużej popularności takich wycieczek może świadczyć fakt, że w całym Związku Radzieckim w 1971 r. uczestniczyło w nich 40 mln osób. Organizowano również marsze po szlakach tematycznych, np. historyczne czy krajoznawcze, a dzięki wytyczeniu szlaków i opisaniu ich w przewodnikach rozwijała się turystyka wodna. Najpopularniejszą rzeką był Dniestr, powyżej Turki, i Czarny Czeremosz - od Burkutu. Brakowało jednak odpowiedniej infrastruktury, m.in. stanic żeglarskich, przystani i portów. Można się domyślać, że turystyka indywidualna istniała, ale $\mathrm{w}$ ograniczonym zakresie (Chazov, 1983; Horbunov, 1969; Jackowski, 1979). Penetracja turystyczna Beskidów Wschodnich na poziomie obwodów i rejonów miała charakter liniowo-węzłowy (z uwagi na bazę noclegową, trasy i szlaki turystyczne), uzdrowiskowa zaś - wybitnie centryczny. 
Narciarstwo było w czasach Związku Radzieckiego częścią szkolenia obronności. Sławsko i Worochta stały się ważnymi stacjami sportów zimowych w skali całej Ukraińskiej Socjalistycznej Republiki Radzieckiej (Struk, 1993). Infrastruktura noclegowa i zaplecze narciarskie były stosunkowo dobrze rozwinięte. W 1962 r. wybudowano dużą skocznię (z igelitową nawierzchnią), a w latach 70. XX w. - siedem wyciągów, wyznaczono także liczne zimowe szlaki górskie i ścieżki biatlonowe. Dzięki tym inwestycjom corocznie rozgrywano w Sławsku i w Worochcie mistrzostwa republikańskich i ogólnozwiązkowych towarzystw sportowych (Burnashov, Hafniak, Hoshovskyi, Drukman, 1973; Fyrsel, 1976; Nabytovych, Protsailo, 2006).

Polityczny wymiar turystyki ujawnił się podczas wyznaczania tras dla zorganizowanych wycieczek. Odbywały się one niemal wyłącznie po stałych szlakach, prowadzonych ze szczególnym uwzględnieniem punktów związanych $\mathrm{z}$ bohaterami narodu lub wydarzeniami II wojny światowej (miejsca bitew, pomniki ku czci sowieckich żołnierzy i partyzantów), a także osiągnięć kolektywizacji i industrializacji. Organizatorzy turystyki zachęcali w ten sposób do selektywnej pamięci o przeszłości "w oparciu o doczesne potrzeby". Lektura przewodników po Beskidach Wschodnich do lat 70. XX w. pozwala stwierdzić, że informacje przydatne turyście indywidualnemu oraz szczegółowy opis bazy noclegowej, gastronomicznej czy rozkłady jazdy, a także lokalizacje sklepów nie były często zamieszczane (Katel, 1968; Qualls, 2006; Peacock, 2014). Przy tej okazji trzeba się zgodzić z Orlovem (2014), który wskazuje, że to czynniki polityczne i ideologiczne determinowały wielkość i geografię wycieczek, a także personel i strukturę grup turystycznych.

O ile w pierwszych latach powojennych ruch turystyczny kierował się głównie do uzdrowisk (pobyty o charakterze leczniczym i wypoczynkowym), o tyle od lat 70. XX w. coraz większą popularnością cieszyły się wycieczki i wędrówki krajoznawcze. Organizowane były przez Centralną Radę Turystyki i Wycieczek we Lwowie, a koordynowane przez kluby terenowe i sekcje tematyczne (m.in. Berkut z Sambora, Borysławski Klub Miejski, kolarski klub „Cyklop” ze Lwowa). Współorganizatorami były również stowarzyszenia młodzieży i ich organy prasowe (np. Lenińska Młodzież). Treść i cel tych wydarzeń często nasycone były wartościami natury ideologiczno-politycznej, co miało odzwierciedlenie w ich nazwach, jak np.: z okazji „100-lecia urodzin Lenina”, ,"54 rocznicy rewolucji październikowej”, , ,XXIV Zjazdu Ukraińskiej i Radzieckiej Partii Komunistycznej” lub „25-lecia wyzwolenia Ukrainy spod okupacji hitlerowskiej". Z kolei z opisów ich przebiegu można wysnuć wniosek, że głównymi przedmiotami zainteresowania turystycznego były walory przyrodnicze, a zwłaszcza krajobrazowe Beskidów Wschodnich. Od początku lat 60. XX w. corocznie odbywały się masowe pochody na Howerlę w Czarnohorze i Pikuj w Bieszczadach, na których notowano wysoką frekwencję. Dla przykładu w 1969 r. w VI Wejściu na Howerlę wzięło udział 1856 osób, w 1970 r. na Pikuj - 3000. Uczestnicy pochodzili z terenów południowo-zachodniej Ukraińskiej SRR, tj. z obwodów: czerniowieckiego, iwanofrankowskiego, lwowskiego, połtawskiego, wołyńskiego, zakarpackiego. Elementy polityczne towarzyszyły także innej masowej formie spędzania czasu wolnego, jaką były zloty i zawody turystyczne, podczas których spotykała się młodzież (w wieku 16-25 lat) z krajów socjalistycznych. Stale tego typu imprezy odbywały się w dolinie Prutu (w Jaremczu, Jabłonicy, Szeszorach, Mikuliczynie i Worochcie) i Oporu (w Kropiwniku, Hrebenowie i Skolem). Uczestnicy podzieleni na wieloosobowe zespoły rywalizowali w licznych konkurencjach (technice turystycznej, orientacji $w$ terenie, wiedzy krajoznawczej i historycznej). W 1969 r. w IX Zlocie „Wesnianka” we wsi Topolnica (obwód starosamborski) struktura narodowościowa młodzieży obejmowała Białorusinów, Bułgarów, Czechów, Estończyków, Gruzinów, Polaków, Rosjan, Tatarów i Węgrów. Można szacować, że rocznie w latach 70. XX w. $\mathrm{w}$ wędrówkach i zlotach organizowanych przez Centralną Radę Turystyki i Wycieczek we Lwowie brało udział ok. 250-300 tys. osób, z czego $80 \%$ w szczególnie popularnych wycieczkach jednodniowych. $Z$ kolei zorganizowane grupy turystów zagranicznych (głównie z państw socjalistycznych) były kierowane przez biuro Inturist do wybranych obiektów noclegowych o najwyższym standardzie. Na terenie Beskidów Wschodnich były nimi przykładowo bazy w Jaremczu („Huculszczyzna”) i na Przełęczy Jabłonickiej (,,Berkut”) (DALO fond 3105, opis 1, sprawa 37, 20; fond 3105 , opis 1 , sprawa 59,5 ; fond 3105 , opis 8 , sprawa 35, 30-156, 222, 259; Jackowski, 1979, Qualls, 2006).

Brak materiałów dotyczących wielkości migracji uczestników kwalifikowanych form turystyki w okresie radzieckim znacznie utrudnia analizę ilościową tego zagadnienia. Na podstawie częściowych danych dotyczących liczby dzieci przebywających na letnich obozach pionierskich na terenie obwodu lwowskiego w prze-

Tabela 3. Liczba dzieci przebywających w pozamiejskich letnich obozach pionierskich na terenie obwodu lwowskiego w latach 1950-1985 (bez obozów miejskich)

\begin{tabular}{|l|l|l|l|l|l|l|l|l|}
\hline Rok & 1950 & 1960 & 1965 & 1970 & 1975 & 1980 & 1984 & 1985 \\
\hline Liczba dzieci w tys. & 14,1 & 21,9 & 29,9 & 35,4 & 40,7 & 35,8 & 36,3 & 38,6 \\
\hline
\end{tabular}

Źródło: opracowanie autorów na podstawie Lvivshchyna... (1982), Lvivska oblast... (1986). 
dziale kilku dekad można dokonać analizy dynamiki ruchu turystycznego. Można jednak z pewnością potwierdzić dużą popularność tego typu infrastruktury noclegowej w latach 70. i 80. XX w. (tab. 3).

\section{PODSUMOWANIE}

Na obszarze Karpat Wschodnich gospodarka turystyczna w okresie radzieckim miała charakter planowy. Zmiana uwarunkowań formalnych i organizacyjnych turystyki pod koniec lat 60. XX w. umożliwiła w kolejnych dziesięcioleciach intensywny rozwój infrastruktury noclegowej. Na lata 70. i 80. XX w. przypada okres największego rozkwitu bazy i ruchu turystycznego w Karpatach Wschodnich. W 51 obiektach przewidziano w przybliżeniu 7300 miejsc noclegowych, zlokalizowanych przede wszystkim w dobrze skomunikowanych dolinach Oporu i Prutu oraz obszarach przyległych. Warto w tym miejscu zaznaczyć, że przed II wojną światową na rozważanym terenie funkcjonowało 141 schronisk, schronów i stacji noclegowych, w których w 1939 r. znajdowało się blisko 4,2 tys. łóżek. Dolina Oporu i Prutu w obu tych okresach stanowiła ważny obszar dla organizacji młodzieżowych i dziecięcych obozów. Worochta i Sławsko utrzymały i rozwinęły funkcję stacji sportów zimowych. Możemy więc mówić o kontynuacji przedwojennej tradycji w tym zakresie.

Po przełomie 1991 r. i kryzysie państwowego finansowania turystyki możemy zaobserwować trzy główne ścieżki funkcjonowania opisywanej w pracy infrastruktury noclegowej dla turystyki kwalifikowanej. Największą grupę stanowią obiekty już niefunkcjonujące, opuszczone, zrujnowane. Można do nich zaliczyć wiele schronisk, np. bazy „Przełęcz" na Przełęczy Tucholskiej, "Źródło Karpat” w Rozłuczu czy „Srebrne Wodospady" w Szeszorach. Z kolei po przekształceniach własnościowych i modernizacji funkcjonują m.in. obiekty w Worochcie, Werchowynie, Kosowie, na Przełęczy Jabłonickiej czy w Skolem i Sławsku, działające w ograniczonym wymiarze. Niektóre budynki z uwagi na atrakcyjne położenie zostały zburzone i zastąpione nowymi, o innej funkcji, np. baza „Prut” i „Huculszczyzna” w Jaremczu. Ze współczesnych obiektów usytuowanych powyżej den dolin można wymienić otwarte w 2008 r. schronisko na Płyściach fundacji „,Karpackie Ścieżki” w Gorganach oraz kilka niezagospodarowanych schronów.

\section{PRZYPISY}

${ }^{1}$ Niniejsza praca stanowi dalszy ciąg rozważań autorów na temat bazy noclegowej na omawianym obszarze. Okres międzywojenny został opisany w artykułach Quirini-Popławskiego (2011, 2018).
2 Szerzej na temat organizacji turystyki w okresie radzieckim w Beskidach Wschodnich pisze Quirini-Popławski (2015).

${ }^{3}$ Ziuzin i Rozhko (2019) podają rok 1959, choć wydaje się to mało prawdopodobne.

4 Podobną strategię w latach 50. i60. XX w. prowadziła Polska Rzeczpospolita Ludowa w stosunku do górskich obszarów ówczesnego województwa wrocławskiego (Potocki, 2009).

\section{BIBLIOGRAFIA}

\section{ŹRÓDŁA RĘKOPIŚMIENNE (WYKORZYSTANE MATERIAŁY ARCHIWALNE)}

DALO (ДАЛО) - Państwowe Archiwum Obwodu Lwowskiego (Державний архів Львівської області)

fond 3105, opis 8, sprawa 35, strony 280: Protokół Centralnej Rady Turyzmu i Wycieczek w Lwowie za rok 1971.

fond 3105, opis 1, sprawa 37, strony 20: zlot klubu Karpaty, Pikuj VI - 1969 .

fond 3105, opis 1, sprawa 59, strony 370: Wykonanie planu Centralnej Rady Turyzmu i Wycieczek w Lwowie w roku 1971.

fond 3105, opis 1, sprawa 61, stron 30: Protokół Ukraińskiej Republikańskiej Rady Turyzmu i Wycieczek, rok 1972.

\section{LITERATURA}

Biesik, T. (2010). Schroniska górskie Beskidu Małego, Ślaskiego, Żywieckiego, Makowskiego i Wyspowego. Bielsko-Biała: Logos.

Biesik, T. (2013). Schroniska górskie dawniej i dziś: Beskid Makowski, Beskid Wyspowy, Gorce, Pieniny i Beskid Sąecki. Bielsko-Biała: Logos.

Bogdziewicz, R. (2012). Schroniska górskie od Beskidu Śląskiego do Czarnohory w latach 1874-1945. Lublin: Wydawnictwo Akademickie WSSP im. Wincentego Pola.

Burnashov, H.V. (1986). Verkhovyna. Uzhhorod: Karpaty.

Burnashov, H.V., Hafniak, N.Y., Hoshovskyi, M.P., Drukman, E.L. (1973). Serebriane lyzhy. Uzhhorod: Karpaty.

Chazov, E.Y. (1983). Kurorty. Moskwa: Sovetckaia Entsyklopedyia.

Czubiński, J. (2008). Nowa architektura w historycznych centrach miejscowości uzdrowiskowych na Huculszczyźnie - Jaremcze, Tatarów, Worochta. Czasopismo Techniczne (Architektura), 105 (6), 33-38.

Czubinski, J. (2014). Identity and identification of the architectural environment in selected health resorts in the Hutsul region's Prut River Valley. W: T. Jeleński, S. Juchnowicz, E. Woźniak-Szpakiewicz (red.), Tradition and heritage in the contemporary image of the city. Tom 2: Challenges and responses (s. 89-95). Kraków: Wydawnictwo Politechniki Krakowskiej.

De Witt, N. (1961). Education and professional employment in the U.S.S.R. Washington: National Science Foundation.

Doljenko, G.P., Putrik YU, S. (2010). Istoriya Turizma v Rossiskoi Imperii, Sovetskom Soyuze i Rossiiskoi Federatsii. Rostov: Izdatelskii Centr "Mart”.

Dolyshnyi, M.Y. (1988). Ukraynskye Karpaty (Ekonomika). Kijów: Naukova Dumka.

Dyląg, D. (2008). Gorgany. Pruszków: Rewasz.

Fedorchenko, V.K., Dorova, T.A. (2002). Istoriia turyzmu v Ukraini. Kijów: Vyshcha shkola.

Fyrsel, N.Y. (1976). Sportyonaia zyma Ukrayny. Kijów: Zdorovia.

Gorsuch, A.E. (2003). „There is no place like home”: Soviet tourism in late stalinism. Slavic Review, 62 (4), 760-785. 
Gudowski, J. (1997). Ukraińskie Beskidy Wschodnie. Monografia krajoznawcza. Warszawa: Dialog.

Hamkało, M., Kudła, N. (2011). Karpaty ukraińskie jako region turystyczny - uwarunkowania i możliwości rozwoju. Prace Geograficzne, 125, 63-75.

Horbunov, N.N. (red.) (1969). Vodnye marshruty Ukrayny. Moskwa: Fyzkultura y sport.

Jackowski, A. (1979). Turystyka w Zwiazku Radzieckim. Warszawa: Szkoła Główna Planowania i Statystyki.

Karashec'kyj, J.Z., Rochnjak, J.A. (2010). Formuvannja arhitektury budivel' girs'kyh turystychnyh prytulkiv. Visnyk Natsionalnoho Universytetu Lvivska Politehnika, 674, 72-78.

Katel, H. (1968). Character training in school and in out-of-school organizations. Activities of the pioneer and komsomol organizations. Soviet Education, 11 (1), 16-48.

Khvostenko, S. (1976). Turyzm na Ukraini. Kijów: Zdorovia.

Kiptenko, V., Lyubitseva, O., Malska, M., Rutynskiy, M., Zan'ko, Y., Zinko, J. (2017). Geography of tourism of Ukraine. W: K. Widawski, J. Wyrzykowski (red.), The geography of tourism of central and eastern European countries (s. 509-551). Cham: Springer.

Kondracki, J. (1978). Karpaty. Warszawa: Wydawnictwo Szkolne i Pedagogiczne.

Konieczniak, J. (2015). Encyklopedia schronisk tatrzańskich. Kraków: Oficyna Wydawnicza Wierchy Centralnego Ośrodka Turystyki Górskiej PTTK.

Korzhev, B.C. (1963). Turystsko-ozdorovytelne laheria. Kijów: Profyzdat.

Kotenko, R.M. (2015). Turystychno-ekskursiina diialnist yak zasib ideolohichnoho vykhovannia naselennia Ukrainy u 70-80-kh rr. XX. st.: Formuvannia instytutsiinoi struktury i zavdan. Karpatskyi Krai, 6-7, 136-143.

Krasyi, R.P. (1976). Yaremcha. Uzhhorod: Karpaty.

Krygowski, W. (1973). Zarys historii polskiej turystyki górskiej. Warszawa: Sport i Turystyka.

Krygowski, W. (1988). Dzieje Polskiego Towarzystwa Tatrzańskiego. Warszawa-Kraków: PTTK Kraj.

Lvivshchyna za roky radianskoi vlady (1982). Lwów: TsSU URSR, Statystychne upravlinnia Lvivskoi oblasti.

Lvivska oblast u tsyfrakh u 1985 (1986). Lwów: TsSU URSR, Statystychne upravlinnia Lvivskoi oblasti.

Maurer, E. (2006). Alpinizm as mass sport and elite recreation: Soviet mountaineering camps under Stalin. W: A.E. Gorsuch, D.P. Koenker (red.), Turizm: The Russian and East European tourist under capitalism and socialism (s. 141-162). London: Cornell University Press, Ithaca.

Mazurski, K.R. (2012). Historia turystyki sudeckiej. Kraków: COTG PTTK.

Moskała, E. (1976). Schroniska sudeckie. Kraków: PTTK.

Moskała, E. (1980). Schroniska PTTK w Karpatach polskich. Warszawa-Kraków: PTTK.

Nabytovych, M., Protsailo, A. (red.) (2006). Mandrivky na vershyny Karpat $z$ turbaz Lvivskoho oblasnoho tsentru kraieznavstva, ekskursii i turyzmu uchnivskoi molodi. Lwów: Holovne upravlinnia osvity i nauky Lvivskoi oblasnoi derzh. administratsii, Lvivskyi oblasnyi tsentr kraieznavstva, ekskursii i turyzmu uchnivskoi molodi.

Nedashkovskaia, N.I. (1983). Rekreatsyonnaia systema sovetskykh Karpat. Kijów: Vyshcha shkola.

Nefedova, V.B., Smyrnova, E.D., Chyzhova, V.P., Shvydchenko, L.H. (1980). Rekreatsyonnoe yspolzovanye terrytoryi y okhrana lesov. Moskwa: Lesnaia promyshlennost.

Olszański, M., Rymarowicz, L. (1993). Powroty w Czarnohorę. Pruszków: Rewasz.

Orlov, I. (2014). The Soviet Union outgoing tourism in 1955-1985 Volume, geography, organizational forms. Moskwa: National Research University Higher School of Economics.
Palmer, N. (2011). Kyrgyz tourism at Lake Issyk-Kul: Legacies of pre-communist and soviet regimes. W: S. Singh (red.), Domestic tourism in Asia: Diversity and divergence (s. 181-196). Singapur: Institute of Southeast Asian Studies.

Peacock, M. (2014). Innocent weapons: The Soviet and American Politics of childhood in the cold war. Chapel Hill: University of North Carolina Press.

Potocki, J. (2005). Przemiany sieci schronisk wysokogórskich w Karkonoszach. Gospodarka Przestrzenna, VIII, 115-123.

Potocki, J. (2009). Funkcje turystyki w ksztattowaniu transgranicznego regionu górskiego Sudetów. Wrocław: Wrocławskie Towarzystwo Naukowe.

Qualls, K.D. (2006). „Where each stone is history”: Travel guides in Sevastopol after World War II. W: A.E. Gorsuch, D.P. Koenker (red.), Turizm: The Russian and East European tourist under capitalism and socialism (s. 163-185). London: Cornell University Press, Ithaca.

Quirini-Popławski, Ł. (2011). Schroniska turystyczne z elementami stylu huculskiego w Czarnohorze i Gorganach do 1939 roku. W: M. Troll, A. Warchalska (red.), Huculszczyzna w badaniach młodych naukowców (s. 131-150). Kraków: COTG, IGiGP UJ.

Quirini-Popławski, Ł. (2015). Organizacja lecznictwa uzdrowiskowego na obszarze Beskidów Wschodnich w latach 1944-1991. W: E. Bilska-Wodecka, I. Sołjan (red.), Geografia na przestrzeni wieków. Tradycja i wspótczesność. Profesorowi Antoniemu Jackowskiemu w 80. rocznicę urodzin (s. 325-347). Kraków: IGiGP UJ.

Quirini-Popławski, Ł. (2018). Infrastruktura noclegowa dla turystyki kwalifikowanej w latach 30. XX wieku na obszarze Karpat Wschodnich (w granicach II Rzeczpospolitej), Prace i Studia Geograficzne, 63 (3), 47-68.

Resnick, A. (1985). Siberia and the Soviet Far East: Unmasking the Myths. Lincoln: GEM Publishers.

Rudenko, H.P. (red.) (1985). Prykarpate. Moskwa: PKO „Kartohrafyia”.

Rutynskyi, M.I. (2012). Rekreatsiino-heohrafichni perevahy, periodyzatsiia ta perspektyvy rozvytku rozlutskoi terytorialnoi kurortno-rekreatsiinoi systemy u Verkhnodnistrovskykh Beskydakh. Heohrafiia ta turyzm, 23, 156-167.

Savchuk, B.P., Kotenko R.M. (2012). Formuvannia orhanizatsiinoi struktury samodiialnoho turyzmu na Prykarpatti u 70-80-kh rokakh XX st. Karpatskyi krai, 1, 93-101.

Shulha, H.M., Onufriv, Y.O. (2013). Evoliutsiia rozvytku hirskolyzhnykh kompleksiv v Ukrainskykh Karpatakh. Mistobuduvannia ta terytorialne planuvannia, 50, 749-758.

Sossa, R.Y. (red.) (1987). Ukraynskye Karpaty. Atlas turysta. Moskwa: Hlavnoe upravlenye heodezyy y kartohrafyy, PKO „Kartohrafyia".

Sovetskoe Prykarpate (1989). Uzhhorod: Karpaty.

Staffa, M. (red.) (1994). Schroniska górskie. Kraków: Sudety.

Stotska, H. (1997). Tsiliushchi vody Skhidnytsi. Lwów: Chervona Kalyna.

Struk, D.H. (1993). Encyclopedia of Ukraine. Tom 4. Toronto-Buffalo-London: University of Totonto Press.

Zavalyi, P.V., Yonkyn, V.S. (1967). Putevodytel avtoturysta po Ukrayne. Kijów: Budyvelnyk.

Zinchenko, V.A. (2004). Molodizhnyi turyzm v Ukrainskii RSR u 70-80-kh rr. XX st. (na osnove deiatelnosty "Sputnyka”). Kijów: Instytut istorii Ukrainy HAH Ukrainy.

Ziuzin, S., Rozhko, I. (2019). Historical aspects of tourist development in the Chornohora massif of Ukrainian Carpathians. Journal of Education, Health and Sport, 9 (1), 335-345.

Artykuł wpłyną: 2 sierpnia $2019 \mathrm{r}$. Zaakceptowany do druku: 28 października $2019 \mathrm{r}$. 